\title{
Relationship between maternal periodontal disease and birth of preterm low weight babies
}

\section{Associação entre doença periodontal materna e nascimento de bebês prematuros e de baixo peso}

\author{
Renata Tolêdo Alves* \\ Rosangela Almeida Ribeiro**
}

\begin{abstract}
It has been recently suggested that periodontal disease is an associated factor for prematurity and low birth weight. The aim of this work was to assess the periodontal status of puerperae and determine its possible relationship with preterm low birth weight (PLBW) delivery. The sample included 59 women seen at two maternity hospitals in Juiz de Fora, MG, Brazil. Nineteen mothers had premature and low birth weight babies (gestational age below 37 weeks and birth weight below 2,500 g - group I), and 40 had mature, normal weight babies (gestational age over 37 weeks and birth weight over 2,500 g - group II). The mothers' data were obtained from medical files, interview, and periodontal clinical examination carried out up to 48 hours after delivery. The Periodontal Screening and Recording (PSR) was used for periodontal assessment. The association between periodontal disease and PLBW was expressed as odds ratio (OR). There was a higher rate of periodontal disease in group I $(84.21 \%-16 / 19)$ as compared with group II $(37.5 \%-15 / 40)$. The data also showed a significant association between periodontal disease and PLBW (OR $=8.9-95 \% \mathrm{CI}: 2.22-35.65-\mathrm{p}=0.001)$. It was concluded that maternal periodontal disease was an associated factor for prematurity and low birth weight in this sample.
\end{abstract}

DESCRIPTORS: Periodontitis; Premature birth; Infant, small for gestational age.

\begin{abstract}
RESUMO: Estudos recentes sugerem que a doença periodontal é um fator associado para prematuridade e baixo peso ao nascimento. O objetivo deste trabalho foi avaliar a condição periodontal de puérperas e determinar sua possivel associação com nascimentos prematuros e de baixo peso (NPBP). A amostra incluiu 59 mães atendidas em duas maternidades de Juiz de Fora, MG. Dentre essas, 19 tiveram bebês prematuros e de baixo peso (idade gestacional menor que 37 semanas e peso ao nascimento menor que $2.500 \mathrm{~g}$ - grupo I) e 40 tiveram bebês a termo e de peso normal (idade gestacional maior que 37 semanas e peso ao nascimento maior que $2.500 \mathrm{~g}-\mathrm{grupo}$ II). Os dados das mães foram obtidos através de prontuário médico, entrevista e exame clínico periodontal, realizado até 48 horas após o parto. O Registro Periodontal Simplificado (RPS) foi utilizado para avaliar a condição periodontal. A associação entre doença periodontal e NPBP foi expressa em "odds ratio" (OR). Os resultados demonstraram uma freqüência maior de doença periodontal no grupo I $(84,21 \%$ - 16/19) em comparação ao grupo II $(37,5 \%$ 15/40). Os dados demonstraram ainda uma associação significante entre a presença de doença periodontal e NPBP (OR = 8,9 - IC de 95\%: 2,22-35,65 - p = 0,001). Concluiu-se que a doença periodontal materna atuou como fator associado para a prematuridade e o baixo peso ao nascimento nesta amostra.
\end{abstract}

DESCRITORES: Periodontite; Nascimento prematuro; Recém-nascido pequeno para a idade gestacional.

\section{INTRODUCTION}

The delivery of preterm (under 37 weeks of gestation) and low birth weight (under 2,500 g) babies continues to be a significant public health issue in both developed and developing countries. This problem is associated with both high postnatal (28 days to 11 months of age) mortality rate, and higher risk of morbidity due to sequelae such as cerebral palsy, blindness, and learning impairment, leading to partial or complete disability. This is one of the most relevant problems in obstetrics. ${ }^{13,15}$
Some factors are traditionally associated with premature and low birth weight babies, namely: maternal genitourinary infections at any time during pregnancy, ${ }^{11}$ low maternal height (under $150 \mathrm{~cm}$ ), lower parental occupational level, and absence of prenatal care. ${ }^{15}$

Knowledge about the pathophysiological features involved in prematurity and low birth weight was refined through advanced techniques developed to investigate pathological processes and lo-

\footnotetext{
* Lecturer in Pediatric Dentistry; **Professor of Pediatric Dentistry - Department of Social and Pediatric Dentistry, School of Dentistry, Federal University of Juiz de Fora.
} 
Alves RT, Ribeiro RA. Relationship between maternal periodontal disease and birth of preterm low weight babies. Braz Oral Res 2006;20(4):318-23.

calized phenomena. Hence, several concepts about diseases have been modified and made more comprehensive. Periodontal disease is one such example. Initially seen as a phenomenon localized to the periodontium, involving the tooth and its underlying tissues, the concept of the disease underwent substantial change as its distant repercussions started being recognized.

Recent studies seem to suggest a slight or moderate association of periodontal disease and preterm low birth weight babies. This association may be heralded by traditional clinical signs found in periodontal disease. ${ }^{1,2,4-6,8,13,15,16}$

The present study aims to determine the prevalence of periodontal disease and its association with the delivery of preterm low weight babies by women giving birth in two maternity hospitals of Juiz de Fora, MG, Brazil.

\section{MATERIAL AND METHODS Study design}

The prevalence of maternal periodontal disease and its association with the birth of preterm low weight babies were determined in a cross sectional study.

\section{Sample}

The study population included 59 women giving birth during the period from September to November 2003 at the Monte Sinai ( $n=25-$ group I: 3 mothers; group II: 22 mothers) and the Therezinha de Jesus maternity hospitals ( $\mathrm{n}=34-$ group I: 16 mothers; group II: 18 mothers), in Juiz de Fora, MG, Brazil. The women were chosen regardless of race and age. They were recruited consecutively among the women attending the maternity hospitals. All the subjects gave their consent, and the study was approved by the Committee for Ethics in Research, University Hospital, School of Medicine, Federal University of Juiz de Fora.

The women were distributed in two groups:

- Group I: women who delivered babies below 37 weeks of gestation and below 2,500 g;

- Group II: women who delivered babies over 37 weeks of gestation and over 2,500 g.

\section{Associated factor identification}

A structured file was initially completed with data regarding identification, general health, gestational history, prenatal care, smoking habits, and dental treatment. The hospital file was consulted for identification and selection of women and their inclusion in one of the groups according to gestational age and birth weight. The structured file was then filled out in a direct interview with the puerpera, at the bedside.

\section{Clinical examination}

The clinical examination of the subjects was carried out within 48 hours after delivery by a single trained and previously calibrated examiner (RTA).

Periodontal probes Ty0112 (Trinity Ind. e Com. Ltda. São Paulo, SP, Brazil), buccal mirrors, gauze, and cotton rolls were used to assess the periodontal status. Clinical examination was carried out with the woman supine on the hospital bed, using slightly modified Periodontal Screening and Recording (PSR) criteria. ${ }^{17}$ The probe was positioned as parallel to the long axis of the teeth as possible. Its active end $(0.5 \mathrm{~mm}$ sphere) was run along the gingival sulcus of all present teeth, with minimum pressure. This probe has a colored band between the $3.5 \mathrm{~mm}$ and $5.5 \mathrm{~mm}$ markers, allowing for quick identification of pockets with this depth and of those deeper than $5.5 \mathrm{~mm}$.

The mouth was divided in six sextants including the following elements: 17-14, 13-23, 24-27, 37-34, 33-43, 44-47. All scores and the highest PSR score for each sextant were recorded in previously structured forms (an absent sextant was recorded as "X").

The scores ranged from 0 to * (asterisk), according to the following criteria:

- code 0: totally visible colored band, without bleeding on probing, without calculus and/or excesses in restoration margins;

- code 1: totally visible colored band, with bleeding on probing, without calculus and/or excesses in the sub- and/or supragingival margins of restorations;

- code 2: totally visible colored band, with bleeding on probing, with sub- and/or supragingival calculus and/or excesses in the sub- and/or supragingival margins of restorations;

- code 3: partially visible colored band $(3.5 \mathrm{~mm}$ to $5.5 \mathrm{~mm}$ pocket);

- code 4: non-visible colored band (pocket larger than $5.5 \mathrm{~mm}$ );

- code *: problems such as furcation involvement, mobility, gingival recession greater than $3.5 \mathrm{~mm}$ and loss of queratinized gingiva.

After the highest score per sextant for each subject was obtained, the highest score among all sextants was considered the general individual score. The collected data provided descriptive in- 
Alves RT, Ribeiro RA. Relationship between maternal periodontal disease and birth of preterm low weight babies. Braz Oral Res 2006;20(4):318-23.

formation regarding the presence and severity of periodontal disease.

\section{Statistical analysis}

The data were typed and analyzed with Epi-Info 2002 (CDC - Centers for Disease Control, Atlanta, Georgia, USA). The dependent variable was low birth weight and/or prematurity. The main independent variable was the indicator of periodontal disease. Independent variables known to influence the incidence of low birth weight, such as smoking, urinary tract infections during pregnancy, concomitant diseases, among others, were taken into account in the analysis as control variables. Continuous and/or polytomic variables were adequately dichotomized for the production of $2 \times 2$ tables, which allowed the calculations of odds ratios (OR). The statistical significance of the results was assessed using 95\% confidence intervals of the association measurements (Odds Ratio or prevalence ratios), and determination of $\mathrm{p}$ values was done using the Chi-squared or Fisher's Exact Tests.

\section{RESULTS}

Graph 1 shows the prevalence of periodontal disease, so considered from a general individual score equal to or greater than 3 , in both groups. In group I, only $3 / 19$ (15.8\%) subjects had scores equal to or lower than 2 , while $16 / 19(84.2 \%)$ had scores greater than 3 . In group II, 25/40 (62.5\%) subjects had an individual score equal to or lower than 2 , while $15 / 40(37.5 \%)$ had scores greater than 3 . These results show a greater prevalence of periodon-

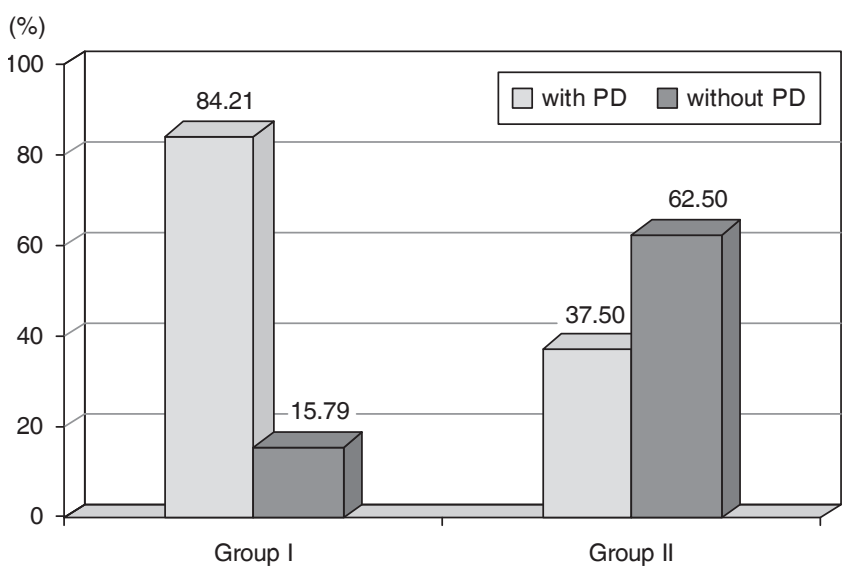

GRAPH 1 - Prevalence of maternal periodontal disease (PD) among women in group I (premature, low weight births) and group II (term, normal weight births), Juiz de Fora, MG, Brazil, 2003. tal disease in group I as compared with group II, a statistically significant difference $(p=0.001)$.

Table 1 shows the distribution of the sample as regards the associated factors assessed. The reference category for each one of the associated factors assessed was marked ( $\mathbf{\square})$. The independent variable smoking habits was not statistically analysed because none of the 59 puerperae had smoking habits.

Among the factors assessed, maternal periodontal disease had the greatest association with prematurity and low birth weight $(\mathrm{OR}=8.9$; $\mathrm{p}=0.001)$.

A number of prenatal consultations lower than six had a significant association with premature, low birth weight babies $(O R=3.49 ; p=0.035)$ in this sample. Primiparity, normally associated with preterm, low birth weight, was a statistically significant protective factor $(O R=0.3 ; p=0.041)$. A history of previous spontaneous abortion was marginally significant $(\mathrm{OR}=3.43 ; \mathrm{p}=0.058)$. The other factors analyzed (age, height, anemia, arterial hypertension, urinary tract infections, diabetes, and gestational weight gain) did not show statistically significant differences between the groups. Data about height, pre-natal consultations and gestational weight were not available for all women.

\section{DISCUSSION}

In 2002, 7,483 children were born in Juiz de Fora, MG, Brazil (Source: MS/SVS/DASIS - Birth information system - SINASC). Of this total, 395 babies were premature and had low birth weight (5.27\% of live births in the municipality). Among the 59 babies included in this study, 19 (32.20\%) were premature and had low birth weight. The percentage of prematurity in this population was therefore much higher than the one expected for the municipality. This higher percentage could be due to the fact that the Therezinha de Jesus Maternity Hospital assists predominantly low socioeconomic level patients, who use the Public Health System of Brazil.

For assessment of periodontal status, Periodontal Screening and Recording (PSR) was used. This index provides an easy, quick, and standardized way of recording individual periodontal status. Furthermore, PSR is considered a sensitive and objective method to diagnose periodontal disease in pregnant women. ${ }^{17}$ In studying periodontal disease clinically there are a lot of potential measures of the disease extent and severity such as clinical attachment level. ${ }^{15}$ However, it was considered im- 
Alves RT, Ribeiro RA. Relationship between maternal periodontal disease and birth of preterm low weight babies. Braz Oral Res 2006;20(4):318-23.

TABLE 1 - Association of factors for prematurity and low birth weight among 59 women seen at two maternity hospitals in Juiz de Fora, MG, Brazil.

\begin{tabular}{|c|c|c|c|c|c|}
\hline \multicolumn{2}{|c|}{ Associated factors } & $\begin{array}{l}\text { Group I } \\
(\mathrm{n}=19)\end{array}$ & $\begin{array}{l}\text { Group II } \\
(\mathrm{n}=40)\end{array}$ & \multirow{2}{*}{$\begin{array}{c}\text { OR }-95 \% \text { CI } \\
1.45(0.12-17.65)\end{array}$} & \multirow{2}{*}{$\begin{array}{l}\mathrm{p} \text { value } \\
0.606\end{array}$} \\
\hline \multirow{3}{*}{ Age } & $<18$ years old & $1 \quad(5.3 \%)$ & $2 \quad(5 \%)$ & & \\
\hline & 18 to 36 years old. & $11 \quad(57.9 \%)$ & $32(80 \%)$ & $1.00(-)$ & $(-)$ \\
\hline & $>36$ years old & $7 \quad(36.8 \%)$ & $6(15 \%)$ & $3.39(0.94-12.35)$ & 0.060 \\
\hline \multirow{2}{*}{ Height } & $<150 \mathrm{~cm}$ & $0 \quad(0 \%)$ & $1 \quad(2.6 \%)$ & - & 0.696 \\
\hline & $>150 \mathrm{~cm} \mathbf{m}$ & $17(100 \%)$ & 38 (97.4\%) & $1.00(-)$ & $(-)$ \\
\hline \multirow{2}{*}{ Anemia } & Yes & $6 \quad(31.6 \%)$ & $15(37.5 \%)$ & $0.77(0.24-2.45)$ & 0.657 \\
\hline & No $\square$ & $13(68.4 \%)$ & $25(62.5 \%)$ & $1.00(-)$ & $(-)$ \\
\hline \multirow{2}{*}{ Hypertension } & Yes & $5 \quad(26.3 \%)$ & $7(17.5 \%)$ & $1.68(0.46-6.22)$ & 0.497 \\
\hline & No $\square$ & $14 \quad(73.7 \%)$ & $33(82.5 \%)$ & $1.00(-)$ & $(-)$ \\
\hline \multirow{2}{*}{ Urinary Tract Infections } & Yes & $7 \quad(36.8 \%)$ & $14(35.0 \%)$ & $1.08(0.35-3.38)$ & 0.890 \\
\hline & No $\square$ & $12 \quad(63.2 \%)$ & $26(65.0 \%)$ & $1.00(-)$ & $(-)$ \\
\hline \multirow{2}{*}{ Diabetes } & Yes & $0 \quad(0 \%)$ & $2 \quad(5 \%)$ & - & 1.000 \\
\hline & No $\square$ & $19(100 \%)$ & $38(95 \%)$ & $1.00(-)$ & $(-)$ \\
\hline \multirow{2}{*}{$\begin{array}{l}\text { Previous Spontaneous } \\
\text { Abortion }\end{array}$} & Yes & $8 \quad(42.1 \%)$ & $7(17.5 \%)$ & $3.43(1.01-11.64)$ & $0.058(+)$ \\
\hline & No $\square$ & $11 \quad(57.9 \%)$ & $33(82.5 \%)$ & $1.00(-)$ & $(-)$ \\
\hline \multirow{2}{*}{ Primiparity } & Yes & $6 \quad(31.6 \%)$ & $24(60 \%)$ & $0.31(0.10-0.98)$ & $0.041(++)$ \\
\hline & No $\square$ & $13(68.4 \%)$ & $16(40 \%)$ & $1.00(-)$ & $(-)$ \\
\hline \multirow{2}{*}{ Pre-Natal Consultations } & $<6$ Consultations & $9 \quad(47.4 \%)$ & $8(20.5 \%)$ & $3.49(1.06-11.46)$ & $0.035(+++)$ \\
\hline & > 6 Consultations . & $10(52.6 \%)$ & $31(79.5 \%)$ & $1.00(-)$ & $(-)$ \\
\hline \multirow{2}{*}{$\begin{array}{l}\text { Gestational Weight } \\
\text { Gain }\end{array}$} & $<18 \%$ & $7 \quad(53.8)$ & $16(45.7 \%)$ & $1.39(0.39-4.97)$ & 0.616 \\
\hline & $>18 \%$ & $6 \quad(46.2 \%)$ & $19(54.3 \%)$ & $1.00(-)$ & $(-)$ \\
\hline \multirow{2}{*}{ Periodontal Disease } & No (Scores from 0 to 2 ) & $3(15.8 \%)$ & $25(62.5 \%)$ & $1.00(-)$ & $(-)$ \\
\hline & Yes (Scores from 3 to *) & $16 \quad(84.2 \%)$ & $15(37.5 \%)$ & $8.90(2.22-35.65)$ & $0.001(+++)$ \\
\hline
\end{tabular}

- Reference Category. +++ Significant. ++ Significant (protection). + Marginally significant.

practical to collect these data under the conditions of the clinical examination. Moreover, comfort of the women was also considered.

The occurrence of periodontal disease in the subjects was compared with the presence of traditionally known associated factors for prematurity and low birth weight. The results demonstrated that periodontal disease was the most significant associated factor among all assessed. Univariate analysis and the chance of prematurity and low birth weight showed an odds ratio $=8.9(p=0.001)$. These results are in accordance with the results from previous studies. . $^{5,9,13,15}$

For Offenbacher et al. ${ }^{15}$ (1997), mothers with periodontal disease are seven times more likely to give birth to premature and low weight babies. Jeffcoat et al. ${ }^{6}$ (2001) found similar results and stated that the risk of premature and low weight births increases four- to sevenfold according to the severity of periodontal disease. Data from Louro et $a l .{ }^{9}$ (2001) support the results found so far, demonstrating that mothers with severe periodontal disease are seven times more likely to have preterm low birth weight. Glesse, Saba-Chujfi ${ }^{5}$ (2003) demonstrated a 12-fold increase in the chances of a woman with severe gingival inflammation, associated to generalized periodontitis or not, delivering a premature, low weight baby. Konopka et al. ${ }^{7}$ (2003) stated that women with severe/generalized periodontitis are three times more likely to deliver a premature, low weight baby. According to Mokeem et al. $^{13}$ (2004), the risk of delivering a premature, low weight baby increases fourfold with an increase of periodontal disease prevalence, regardless of the control of other risk factors such as age, smoking, and social extraction. Cruz et al. ${ }^{2}$ (2005) found a positive association between periodontal disease and low birth weight especially among the mothers 
Alves RT, Ribeiro RA. Relationship between maternal periodontal disease and birth of preterm low weight babies. Braz Oral Res 2006;20(4):318-23.

with schooling of less than or equal to four years. López et al. ${ }^{8}$ (2005) underlie such association, their data showing that periodontal disease increases the chances of delivering premature, low weight babies fourfold.

Results from the study of Rajapakse et al. ${ }^{16}$ (2005) were only suggestive of an association between periodontal disease and preterm low birth weight, perhaps indicating that previously reported associations might have been subjected to residual confounding due to tobacco, alcohol, and drug use.

Conversely, in the study conducted by Mitchell-Lewis et al. ${ }^{12}$ (2001), the rate of maternal periodontal disease was not significantly different for premature or mature babies. It is noteworthy that only four women in that study had a diagnosis of generalized juvenile periodontitis. If the sample had been larger, with greater prevalence of periodontal disease, the results might have been different, since the authors reveal that periodontal therapy before delivery reduces the incidence of premature, low weight births in $28.6 \%$. Davenport et al. ${ }^{4}$ (2002) ruled out any association of maternal periodontal status and the delivery of premature, low weight babies $(\mathrm{OR}=0.83)$. Lunardelli, Peres ${ }^{10}$ (2005) did not find association between maternal periodontal disease and low birth weight. An association between prematurity and periodontal pockets was found but it was confounded by maternal health variables. Noack et al. ${ }^{14}$ (2005), using a logistic regression model for controlling known preterm low birth weight risk factors, concluded that periodontitis was not a detectable risk factor for preterm low birth weight in pregnant women.

As for the other associated factors assessed (Table 1), the results revealed that only fewer than six pre-natal consultations and a previous history of abortion are significant risks for the birth of premature, low weight babies. Primiparity also presented statistically significant results in the present population, although performing as a protective factor, more associated with delivery of mature, normal weight babies. The fact that primiparae are more likely to be motivated to undergo pre-natal care, thus reducing final risk, might account for this finding.

Periodontal disease, as a Gram-negative infection, may have the potential to interfere with pregnancy outcome. The underlying biological mechanism has not been well defined. A possible justification is based on an increased gingival fluid from gingival inflammation, blood-borne inflammation mediators reaching the placental membranes and inducing premature labor. ${ }^{3}$ New evidence suggests that the association of maternal periodontal disease and prematurity may be better indicated by the levels of inflammation mediators such as prostaglandin $\mathrm{E}_{2}\left(\mathrm{PGE}_{2}\right)$ and interleukin 1 beta (IL$1 \beta)$ in the gingival fluid. ${ }^{1,7}$

The identification of associated factors for premature and low weight births is very important for public health as it represents a target for the development of preventive strategies aimed to reduce the prevalence of that condition. This study showed evidence that maternal periodontal disease is associated with a higher risk of premature, low weight births. Although the study population may be considered relatively small, the statistical significance of the results found $(\mathrm{p}=0.001)$ cannot be left out of account. Although multivariate analysis was not conducted, periodontal disease was the factor more strongly associated to these births in this sample, followed by the number of prenatal consultations (fewer than $\operatorname{six}-p=0.035$ ) and a history of previous spontaneous abortion $(\mathrm{p}=0.058)$.

The available data point to periodontal disease as an associated factor for the birth of premature, low weight babies, a fact confirmed in this investigation.

Further multidisciplinary studies could be carried out to better define data collection criteria for assessment of other acknowledged associated factors for such births. Furthermore, the time is ripe for the investigation of the association of maternal periodontal disease and the preterm low birth weight babies, through laboratory studies. Such studies would integrate dentistry and medicine, contributing for the assessment of features that may be important for the general and oral health of mothers and children.

\section{CONCLUSION}

In conclusion, within the limits of this study, periodontal disease was an associated factor for birth of preterm low weight babies, among the 59 subjects studied, suggesting that an assessment of periodontal disease should be included in prenatal care programs. 
Alves RT, Ribeiro RA. Relationship between maternal periodontal disease and birth of preterm low weight babies. Braz Oral Res 2006;20(4):318-23.

\section{REFERENCES}

1. Carta G, Pérsia G, Falciglia K, Iovenitti P. Periodontal disease and poor obstetrical outcome. Clin Exp Obstet Gynecol. 2004;31(1):47-9.

2. Cruz SS, Costa MCN, Gomes Filho IS, Vianna MIP, Santos CT. Maternal periodontal disease as a factor associated with low birth weight. Rev Saúde Pública. 2005;39(5):782-7.

3. Damare SM, Wells S, Offenbacher S. Eicosanoids in periodontal diseases: potential for systemic involvement. Adv Exp Med Biol. 1998;433:23-35.

4. Davenport ES, Williams CE, Sterne JA, Murad S, Sivapathasundram V, Curtis MA. Maternal periodontal disease and preterm low birthweight: case control study. J Dent Res. 2002;81(5):313-8.

5. Glesse S, Saba-Chujfi E. A influência da doença periodontal no trabalho de parto pré-termo [abstract]. Pesqui Odontol Bras. 2003;(17 Suppl 2):155.

6. Jeffcoat MK, Geurs NC, Reddy MS, Goldenberg RL, Haulth JC. Periodontal infection and preterm birth: results of a prospective study. J Am Dent Assoc. 2001;137(7):87580.

7. Konopka T, Rutkowska M, Hirnle L, Kopec W, Karolewska $\mathrm{E}$, Rutkowska $\mathrm{M}$ et al. The secretion of prostaglandin $\mathrm{E}_{2}$ and interleukin 1-beta in women with periodontal diseases and preterm low-birth-weight. Bull Group Int Rech Sci Stomatol Odontol. 2003;45(1):18-28.

8. López NJ, Da Silva I, Ipinza J, Gutiérrez J. Periodontal therapy reduces the rate of preterm low birth weight in women with pregnancy-associated gingivitis. J Periodontol. 2005;76(Suppl 11):2144-53.

9. Louro PM, Fiori HH, Louro Filho P, Steibel J, Fiori RM. Doença periodontal na gravidez e baixo peso ao nascer. $\mathrm{J}$ Pediatr. 2001;77(1):23-8.
10. Lunardelli AN, Peres MA. Is there an association between periodontal disease, prematurity and low birth weight? A population-based study. J Clin Periodontol. 2005;32(9):938-46.

11. Minkoff H, Grunebaum AN, Schwartz RH. Risk factors for prematurity and premature rupture of membranes: a prospective study of the vaginal flora in pregnancy. Am J Obstet Gynecol. 1984;150(8):965-72.

12 Mitchell-Lewis D, Engebretson SP, Chen J, Lamster IB, Papapanou PN. Periodontal infections and pre-term birth: early findings from a cohort of young minority women in New York. Eur J Oral Sci. 2001;109(1):34-9.

13. Mokeem SA, Molla GN, Al-Jewair TS. The prevalence and relationship between periodontal disease and preterm low birth weight infants at King Khalid University Hospital in Riyadh, Saudi Arabia. J Contemp Dent Pract. 2004;5(2):40-56.

14. Noack B, Klingenberg J, Weigelt J, Hoffmann T. Periodontal status and preterm low birth weight: a case control study. J Periodontal Res. 2005;40(4):339-45.

15. Offenbacher S, Katz V, Fertik G, Collins J, Boyd $\mathrm{D}$, Maunor $\mathrm{G}$ et al. Periodontal infection as a possible risk factor for preterm low birth weight. J Periodontol. 1997;67(10):1103-13.

16. Rajapakse OS, Nagarathne M, Chandrasekra KB, Dasanayake AP. Periodontal disease and prematurity among non-smoking Sri Lankan women. J Dent Res. 2005;84(3):274-7.

17. Rosell FL, Monttandon-Pompeu AAB, Valsecki Jr. A. Registro periodontal simplificado em gestantes. Rev Saúde Pública. 1999;32(2):157-62.
Received for publication on Feb 17, 2006

Sent for alterations on May 24, 2006 Accepted for publication on Jul 17, 2006 